\title{
The Impact of Black Studies Programs on the Academic Library
}

\begin{abstract}
Black studies is an educative program aimed toward eliminating the distortions and biases of traditional curricular programs. Though sometimes revolutionary, it strives to instill in black people a sense of identity, unity, and group dignity, and boldly rejects the host of standards traditionally dictated by white Americans. For the white student it offers an understanding of the black experience, and for all students it aspires to widen the channels of communication and broaden understanding among individuals of all races. The creation of these programs has variously affected the development of collections in academic libraries. It is doubtful that black studies programs will be effective agents of change until anxieties level off and more realistic approaches to the problem of developing academic libraries and their collections are formulated.
\end{abstract}

\section{$T_{1}$} HAPIDLY GROWING RECOGNITION of black studies has been a noteworthy development in American education during the past few years. As years go by and we attempt to put the history of American education into perspective, we will undoubtedly view the decade of the 1960 s as one in which issues of "integration, busing, nonviolence, violence, freedom now, law and order, black power, community control, white racism, institutional racism, separatism, black nationalism, revolution, and black studies" ran rampant. ${ }^{1}$

But what are black studies? What are Afro-American, or Negro studies? Their role, as perceived by many advocates of black studies programs, is to counteract the fundamentally white studies programs to which all American students have been subjected throughout their educational careers. The observation is

Mrs. Smith is university librarian at Fisk University, Nashville, Tennessee. inescapable that American educational philosophy has long reinforced a rather one-sided, distorted view of American historical and cultural development. Consider for a moment the multitude of history courses which have ignored the fact that slavery once existed in such states as Connecticut, or that many American slaves actively rebelled against their servitude. Or consider the omission of Phillis Wheatley's poetry in standard American literature texts. While both black and white students have encountered Marx in their philosophy courses, they have not been exposed to W. E. B. DuBois. The inconsistencies are irrefutable.

Stated succintly, black studies is a curricular program aiming to assess the extent of the black man's involvement in the American cultural experience. It strives to instill in black people a sense of identity, unity, and group dignity, and boldly rejects the host of standards traditionally dictated by white Americans 
governing fashion, hair styles, skin coloring, and speech patterns. It is not only blacks, however, who have been deprived of an accurate portrayal of the black man. White Americans have also been provided little basis for understanding black culture; biased textbooks and cultural indoctrination have perpetuated a distorted perception of American cultural heritage among both blacks and whites.

"Black Studies" is in essence an educative program. It must admit to ideological indoctrination, but only to the extent that it attempts to eliminate the distortions and voids traditionally characteristic of curricular programs. Black studies aims to prepare blacks to participate more fully in academic and cultural activities. It provides both black and white students with the knowledge and insight requisite to mitigating the poverty and racial tension so devastating to the black ghetto dweller. It aims to develop a sense of identity and dignity among blacks, and for white people who are willing to relinquish their traditional dogmas, it offers a healthier and more sensitive approach to life. Ultimately, black studies aspires to widen the channels of communication and broaden understanding among individuals of all races.

"Afro-American Studies" is but a rose by another name. It is a term frequently used by individuals who, for reasons of their own choosing, object to using the word "black" in this racial context. Others interpret the term "Afro-American" in a much broader sense, intimating that black heritage is both African and American.

"Negro Studies" is now infrequently used, if indeed used at all. Using the term "Negro" here just does not do what needs to be done. It reflects a conservative way of thinking, and seems to suggest a quality of compatibility vis-à-vis the Establishment. Moreover, it tends to be devoid of the attitudes and seriousness of intent needed to deal adequately with the injustices and distortions levied against black people. Above all, it implies rejection of the heated demands of the black students who are supporting the black studies movement so conscientiously. The term "Negro Studies" merely suggests the type of middle-class black Sambos who would be produced from such a program.

Unlike Topsy, black studies did not just grow. Nor did it originate in any orderly, systematic manner. The black studies programs initially created in some institutions resulted directly from pressure exerted by black student groups. Pressure came in the form of "non-negotiable demands." Such demands, however, are not peculiar to black students. Many young people who have become fed up with the status quo, the Establishment, and the hypocrisy of the day resorted to expressing their disenchantment via "non-negotiable demands," strikes, destruction, obstruction, and frequently through violence. Although the motivating forces behind these acts will not be treated here, it must be pointed out that the reactions of all those who have been involved in these activities, whether students, faculty, or outside agitators, have played a part in encouraging or perpetuating this behavior.

Black studies is not new. Even during the pre-Civil Rights Bill era, individuals who were educated in the historically black institutions, located primarily in southern states, were introduced to some form of black studies. Courses in what was then called "Negro History" have been offered at these institutions for about as long as the institutions have existed. In some of these schools, this course was even a requirement for graduation. In those elementary and high schools where blacks were segregated from whites, and where forward-thinking black instructors were employed, black studies was incorporated into courses in literature and history, albeit not identifiable as such. What is new, however, is the great thrust toward black studies. 
It was not until the Black Power movement of the late 1960s gained attention that American educational institutions gave any serious consideration to black studies programs. Even after the passage of the Civil Rights Bill in 1954, there was no widespread effort to reform curricular programs or initiate programs with a black emphasis until the fears of burnings, rioting, and looting were felt on college campuses. Finally, in the wake of the new black studies boom, institutions began at long last to assume their educational responsibilities toward black students. In 1968, thirty-three institutions offered black studies in Illinois; by 1969, that number had risen to sixty-five. ${ }^{2}$

Black studies programs at Cornell, Harvard, Yale, and San Francisco State are frequently cited among the outstanding black studies programs in the nation. Two years ago, educational consultant Joseph Colemen identified twenty-three colleges which planned to offer bachelor degrees in black studies by the fall of 1970. In 1969, the American Council on Education reported that approximately 480 colleges and universities were planning or examining black studies programs. ${ }^{3}$

A proliferation of black studies programs is evident throughout the country. These programs were established to rid the world of the "invisible man" concept, as C. Vann Woodward terms it. ${ }^{4}$ Rather than continue to ignore the black man and deprive him of identity, the programs strive to affirm his rightful place in history. They recognize the twodimensional man who DuBois discusses in The Souls of Black Folk. The black man senses his duality; he is "an American, and a Negro; two souls, two thoughts, two unreconciled strivings; two warring ideals in one dark body. ..." Traditional white studies programs have consistently prevented the black man from feeling either American or Negro. He has been unable to study himself, due partly to the fact that he has not been recognized in history, literature, or the arts. His tragedy has been, as DuBois once put it, his sense of double-consciousness-a sense of always looking at himself through the eyes of others, if indeed looking at himself at all.

Three distinct points of view can be identified among advocates of black studies programs.

\section{SEPARATIST APPROACH}

The first point of view was represented at Antioch College, where an all-Negro black studies institute was recently established. Like many other black studies programs, this institute originated via "nonnegotiable demands" to establish a program and keep it black. The program aimed to incorporate ideas espoused by Nathan Hare, then at San Francisco State; according to Hare, the objective of a black studies program is ". . . to deal with the problems of the society which produced and perpetuates the predicament of blacks." ${ }^{\prime \prime}$ Many black students would like to see autonomous black studies programs, i.e., programs administered, taught, and attended uniquely by blacks. Proponents of such a program feel that white instructors are incapable of fully understanding black problems and the black experience. Unlike these proponents, however, Nathan Hare does not believe that whites should be excluded. He merely insists that blacks be taught to deal with society.

The U.S. Department of Health, Education, and Welfare sanctioned, in effect, a "separate but equal" doctrine when it permitted Antioch to operate an allNegro black studies institute. The situation at Antioch is perhaps best expressed in Kenneth B. Clark's letter of resignation from the Board of Directors of Antioch College. Clark, a noted black psychologist and author, expressed strong opposition to the college's decision to participate in a form of racial exclusion, even though it was a mere reversal of 
the racial exclusion that blacks have known traditionally:

To exclude someone of one race- or admit that it would be appropriate to do so- on the grounds that his background or experience are irrelevant, that they render him unable to achieve is precisely what white segregationists have been doing to blacks for centuries. Yet this seems to be the burden of rationalization at Antioch for a black separatist policy. Yet, it is whites who need a Black Studies program most of all.

The white liberal for his part who concedes black separatism so hastily and benevolently must look to his own reasons, not the least of them perhaps an exquisite relief. To encourage or endorse a separate black program not academically equivalent to the college curriculum generally, indeed to endorse any such program, is to reinforce the Negro's inability to compete with whites for the real power of the real world. It is no excuse to justify the deed by citing the demand....

I believe that above all under times of tension, stress, and pressures to conform to the shouting demands of the populace, colleges must have the courage to stand firmly for the rule of reason and for those principles and values considered indispensable to serious education. I do not believe that Antioch, in acceding to the demands for a separate facility for its Negro students, has showed this type of courage. I do not believe that Antioch, in permitting some of the more hostile Negro students to coerce and intimidate other Negroes and whites by quashing vocal dissent, has showed the courage necessary to maintain that type of academic climate which permits man that freedom of inquiry, freedom of thought, and freedom of dissent which are essential to the life of the intellect. ${ }^{7}$

\section{INTERDISCIPLINARY APPROACH}

One advocate of the second point of view regarding the organization of black studies programs is Martin Kilson. Kilson, a professor of government at Harvard, was the only black member of the Harvard Faculty Committee on African and Afro-American Studies which pre- pared a report analyzing the feasibility of introducing an undergraduate major in Afro-American studies at Harvard. The viewpoint espoused by Kilson may well be the one most widely accepted among proponents of black studies programs. Kilson maintains that militant advocates of black studies programs who refute the essentially interdisciplinary nature of black studies have little to contribute to the formal organization of these programs. He suggests that the student of black studies first ground himself in related disciplines such as history, economics, political science, and sociology.

This point of view argues that the most effective black studies programs are those which require the prospective major to fulfill academic requirements in the established disciplines and simultaneously enroll in black studies courses. If indeed black studies aims to expand the black man's cultural experience, to approach it as an isolated curriculum is self-defeating.

At Harvard, the Afro-American studies program initially included eight courses. These were: "Africa and World Politics," "Blacks in Labor and Politics," "Black Civilization," "A Philosophy and Critique of the Black Revolution," "Poetry of the American Negro," "Legal Rights and Remedies," "The Black Community of Boston," and "African and West Indian Literature." The W. E. B. DuBois Institute for Afro-American Research was later established at Harvard. The director of the Afro-American studies program asserted that the principal problem relating to race relations and the black community can be traced to the attitudes of whites toward blacks. He shared Nathan Hare's conviction that Afro-American courses are as relevant to whites as they are to blacks. The Harvard program is interdisciplinary, and even incorporates fieldwork in black neighborhoods.

Analysis of the black studies curricula at Berkeley reveals that courses in anthropology include "Survey of African An- 
thropology," "Survey of Afro-American Anthropology," and "Comparative Black Anthropology." The art department offers "Survey of African Art" and "Contemporary Afro-American Art." The dramatic arts curriculum includes "AfroAmericans and the Theater," and the economics department offers a course entitled "Economics of Racism." "Survey of Afro-American Literature" and "The Black Writer in America" are sponsored by the English department. The history department offers a course called "U.S. History from a Black Perspective," and interestingly enough, linguistics and communications courses included "Language of the Ghetto," "Black Speech Styles," and "Black Nonverbal Communication."

Courses offered through the School of Music include "Music and the Black Man," "Contemporary Afro-American Music," and "History of African Influence on Western Music." "Black Thought in the 20th Century" is offered in philosophy, while "Political Problems of Black Americans" and "The American Government-Black Perspective" are offered in political science. Students of psychology may enroll in such courses as "Psychology of Racism" and "Black Economic and Social Psychology." Courses in social welfare include "Social Welfare Legislation" and "Policy from the Black Perspective." Finally, courses in sociology include "Sociology of the Black Family," "Black Social Movements," "Black Social Institutions," and "Urbanization of Black People."

Courses similar to those taught at Harvard and Berkeley are offered in black studies programs at other institutions. Some highly specialized courses have raised the eyebrows of individuals who question the validity or wisdom of establishing courses which accommodate the whims of angry students. Courses in "Soul Food Cooking," prevalent in a number of black studies programs, are frequently cited as being too overtly reconciliatory.

\section{INTEGRATEd STUdies APPROACH}

The third and final point of view argues that a separate black studies program, as such, should not be established in the first place. Proponents agree in part with those who favor the interdisciplinary approach, but they contend that it is our collective responsibility to shatter the prevailing illusion that the black man has made no appreciable contribution toward the shaping of human destiny. It is of utmost importance that each man learns to view himself within the context of his own environment. The "invisible man" approach is too shallow and ambiguous to validate the account of any people's history.

Dr. Stephen J. Wright, former president of Fisk University, has examined some of the problems which arise when black studies programs are established on a crash basis. He found that such programs tend to foster nonexperts, a result he attributes partially to the paucity of teachers who are qualified to meet the needs of black studies programs. ${ }^{8}$

Black studies programs which are conceived in panic or frustration will not progress far beyond infancy. American higher education cannot placate the impassioned hopes and pleas of idealists at the expense of sound educational and intellectual objectivity. Justification for an integrated studies program is often rooted in the belief that black history and literature cannot be perceived as meaningful unless they are presented in a cosmopolitan context. In this regard, Roy Wilkins cautions against what he terms "racial breastbeating." Wilkins contends that his generation discovered ways to learn about the black man and his past long before black studies curricula were popularized. ${ }^{9}$

The Anglo-Saxon orientation toward higher education must be replaced by a more socially conscious one. Some individuals believe that black studies, as well as all other curricula, should be incor- 
porated into the study of all peoples and all nations-i.e., a fully integrated, interdisciplinary program. These individuals contend that autonomous black studies programs are simply not necessary.

Whichever viewpoint one takes is a matter of individual prerogative. What remains indisputable, however, is the present surge of interest in promoting black studies programs. The Ford Foundation and the National Endowment for the Humanities have jointly sponsored summer and year-long institutes to teach faculty members to teach courses in this field. These institutes were designed to provide in-depth coverage of black history, art, and literature, as well as a general survey of the field of black studies.

Black institutions are meeting the demands for black studies by adopting one of the types of programs already described, or by incorporating the concept of the Black University movement into the development of future trends and directions. While this movement may have been misunderstood, misinterpreted, and misguided by many educators and administrators, it has in varying degrees affected every one of the historically black institutions. Vincent Harding, director of the Institute for the Black World in Atlanta, argues that the call for a black university has nothing to do with separation or integration. He justifies the establishment of the black university as follows:

1. The black university seeks to break the long-established familiar pattern of white domination and control over black higher education.

2. It marks a clear break with the basic idea that black students should be prepared to live in a world defined and controlled by whites.

3. The black university and its students are guided essentially by the central purpose of service to the black community on every technical and personal level possible.
4. It is a movement to define education as being unashamedly political, and ties black higher education to the struggles of African peoples everywhere.

5. It is the creation of new institutions and new modes of thought on behalf of a new humanity.

6. It is a place where black people demand of each other more disciplined commitment to intellectual and physical work than ever before.

7. It calls into question white universities and challenges their adequacy and response to the most urgent needs of modern society. Black institutions are no longer needed as poorer, carbon copies of white institutions, for we now have access to the white original models where some token integration exists. ${ }^{10}$

Dr. Harding asserts that the concept of a black university is not entirely new. W. E. B. DuBois, John Hope, and Marcus Garvey are a few of the outstanding black personalities who "caught the vision" early. These men pioneered and advanced this concept in their writings and actions.

Stephen Henderson suggests that the black university should offer experiences of blackness-not indoctrination into blackness but saturation of the black experience. Simply stated, the student will absorb as much of this experience as he can, or as much as he needs to find his identity. Henderson maintains that saturation is realized only when the black man "understands, accepts, utilizes and celebrates his blackness." Saturation, he believes, is a condition, a goal, a mechanism, or process for reaching a goal, and a strategy for reaching a condition. The ultimate product of this type of saturation is black liberation. ${ }^{11}$

What, then, is the future of black studies? It is impossible to predict where black studies will take us, for there is no common blueprint for developing and maintaining black studies programs 
These programs tend to be tailored more or less to the taste of those who create them, and sometimes by those who demand them. Some effort, however, is being exerted to coordinate programs through institutes and conferences. Yet even if there existed a common blueprint for developing and maintaining black studies programs, who could predict their future course?

There are, however, a number of predictions which can be made with certainty:

1. The new black awareness and black experience which have been fostered to some extent by black studies programs will continue.

2. History, literature, the arts, and other curricular programs in our universities, whether offered as separate black studies programs or not, will continue to include some study of the black man. The black man, as an "invisible man," will disappear.

3. For more years than we care to admit, the black man will continue to be two-dimensional, as DuBois perceived him. He will continue to feel his twoness, his American and Negro identities. One function of black studies programs and black universities will be to rid the black man of these conflicting feelings while simultaneously educating white Americans to accept black people more fully.

4. The integration of black studies curricula into other disciplines will become more extensive. Black studies curricula will not become the ebony tower that some militants advocate.

5. The replacement of white studies, or Anglo-Saxon studies, by studies geared more to the needs of all people will gradually take place. Through exposure to a new integrated studies curriculum, both black and white students will become more cognizant and apprecia- tive of races other than their own.

6. The inequities that exist in our educational system have long endured, and they will continue to filter through our educational system until all men unite in an effort to eliminate them. Black studies programs are merely a first step in the right direction-the real task lies in the hands of those who shape our educational system.

\section{Impact of Black Studies Programs ON THE ACADEMIC LIBRARY}

Now that we have defined black studies, explored their patterns of development, and offered some predictions regarding the future of these programs, we can proceed to assess the impact of these programs on the academic library.

By effectuating certain modifications in general collections, special collections, services, programs, and staff, black studies programs have already influenced the development of academic libraries. Even so, the real impact of these new programs has yet to be felt. It is doubtful that black studies programs will be effective agents of change until anxieties level off and more realistic approaches to the problem of developing academic libraries and their collections are formulated. Until that time, however, at least ten different areas can be identified in which black studies programs have affected the academic library:

1. Token collections of black literature have long been housed in certain white as well as in traditionally black institutions. As the black studies boom gained momentum, however, many academic libraries were caught napping. While new efforts were made to assemble collections of materials revealing the black experience, they were usually motivated by a desire to pacify demanding students. Although many of these instant collections 
mushroomed, too little thought and planning went into them to increase their stature to any significant degree.

2. Other libraries have developed special collections of black literature which do not reflect the instant collection syndrome. These collections were organized by culling the shelves for black-related materials and adding to these newer titles available on the book market. Such collections were frequently assembled in order to serve more fully the requirements of a well-defined, interdisciplinary black studies program. Communities in which little or no black literature is available to the public have occasionally called upon the academic library to establish a collection as a community service.

3. An impoverished assemblage of black studies materials is developing in some academic libraries. Many of these materials, whether they are available in a special collection or not, are gathered by persons who know nothing about black literature or black authors. Many of these individuals resort to combing catalogs of publishers and reprint dealers, selecting everything listed under the heading of "Black Studies" or with the word "black" in its title. While sizeable amounts of money are invested in such efforts, the resulting collections are frequently as shabby as the manner in which they are assembled. Like southern politicians, many librarians may be trying too hard to "do the right thing." They need to reduce their pace and seek to develop their collections in an orderly and systematic manner; they must be careful to select prudently from as many subject areas as possible, insuring that many viewpoints are represented in the materials they gather.

4. There has been a clarion call for consultants in black literature. Many libraries are conscious of the inadequacies of their black studies collections, and of their limited knowledge of black literature and black experience. Many librarians are anxious to develop good collections and supplement their Anglo-Saxon collections with materials which reveal more completely the true American heritage. To guard against building an instant or mediocre black studies collection, these librarians consult experts in the field before making their selections.

5. Some librarians unfamiliar with black bibliography, literature, and history are beginning to take advantage of black studies programs by enrolling in courses which introduce them to black literature. Unfortunately, however, too few librarians are taking advantage of this opportunity.

6. Many libraries, particularly learning resources centers, are beginning to place greater emphasis on black media. As publishers and agencies produce materials in an ever-increasing variety of formats, libraries are keeping pace by collecting and building resources which incorporate the sights and sounds of black people. Recordings of black poets reading their works, slides of primitive African art, films of performing black actors and actresses, and documentaries telling the story of the black experience are all becoming a part of black studies resources in libraries.

7. Much energy is currently being channeled into the collection of original research materials in order to preserve the black heritage. 
Black libraries are making a special effort to expand and preserve their archives, which are rich and invaluable sources of information. Moreover, they are attempting to gather the uncollected papers and works of black people which up until now have been gathering dust in attics and basements throughout the country. Once these materials are located, collected, and processed, scholars will have access to a wealth of information which is conspicuously absent today.

8. In addition to enabling libraries to establish a well-rounded, nonracially biased collection of black materials, black studies has helped strengthen the collections already in existence at such institutions as Howard, Fisk, Atlanta, Hampton, Tuskegee, Harvard, UCLA, and the Schomburg Collection of the New York Public Library. For many years, these collections provided the primary and secondary research materials which scholars used to produce the materials which many libraries are collecting today.

9. Black studies programs have called for greater library cooperation in providing materials needed to support the programs. For example, libraries at Fisk, Atlanta, and Oberlin have made parts of their collections available to other libraries through reprint programs and/or microform projects. Other libraries, including those at Bennett, Greensboro, and Guilford colleges in North Carolina, have formed consortia as a means of increasing the availability of collections and resources. By making its own specialized black studies collection available to other member libraries, one library can effectively eliminate the necessity for the others to collect in that area.

10. The greater utilization of black collections on the part of students, faculty, and researchers is perhaps the most obvious effect that black studies has had on the academic library. Moreover, the variety of materials needed to support the new curriculum are in greater demand throughout the academic community.

\section{SUMMARY}

We have analyzed the relationship between black studies programs and academic libraries, and defined these programs as endeavors to put the black man into proper historical perspective. Black studies provides training in significant fields of intellectual inquiry. It rejects the dogmas which have traditionally disregarded the black experience, and favors an approach to life which requires greater interracial understanding and communication.

We have identified several patterns of development in black studies programs: the separate program for black students only; the separate program for all students, requiring proficiency in established disciplines; the fully integrated program offered as a part of the regular curriculum; and the black university concept, which is obviously confined to the black academic institution.

It will be possible to assess more fully the impact of this new curricular program on the academic institution once the academic community assumes its responsibility to all people with deliberation, dedication, and wisdom. While many libraries have made great strides in building collections to support black studies, others, to paraphrase Langston Hughes, are merely deferring their dreams. We do not yet know what happens to a dream deferred, but it is clear that we dare not allow it to "dry up like a raisin in the sun." ${ }^{12}$ It is our 
responsibility as educators and librarians to dispel the "invisible man" concept by developing programs and resources which meet the needs of all Americans.

\section{REFERENCES}

1. Charles V. Hamilton, "The Question of Black Studies," Phi Delta Kappan 51:362 (March 1970).

2. William W. Brickman, "The Black Studies Bandwagon," School \& Society 98:140 (March 1970).

3. "Black Studies Studied; American Council on Education Reports," America 120:698 (21 June 1969).

4. C. Vann Woodward, "Clio with Soul," Black Studies Myths and Realities, A. Philip Randolph Educational Fund (Sept. 1969), p.18.

5. W. E. B. DuBois, Souls of Black Folk (Chicago: A. C. McClurg \& Co., 1922), p.3.

6. Nathan Hare, "What Black Studies Mean to a Black Scholar," College \& University Business 48:58 (May 1970).

7. Kenneth B. Clark, "Letter of Resignation from Board of Directors of Antioch College," Black Studies Myths \& Realities, A. Philip Randolph Educational Fund (Sept. 1969), p.33.

8. Stephen J. Wright, "Black Studies and Sound Scholarship," Phi Delta Kappan 51:367 (March 1970).

9. Roy Wilkins, "The Case Against Separatism: 'Black Jim Crow,'” Black Studies Myths \& Realities, A. Philip Randolph Educational Fund (Sept. 1969), p.38-39.

10. Vincent Harding, "Toward the Black University," Ebony 25:157 (Aug. 1970).

11. Stephen Henderson, "Toward a Black University," Ebony 25:114-15 (Sept. 1970).

12. Langston Hughes, "Harlem," Langston Hughes and Arna Bontemps, eds., The Poetry of the Negro, 1746-1970 (New York: Doubleday and Co., 1970), p.199. 